\title{
Lembaga Negara Independen Di Indonesia Dalam Perspektif Konsep Independent Regulatory Agencies ${ }^{1}$
}

\author{
Rizki Ramadani \\ Fakultas Hukum Universitas Muslim Indonesia Makassar \\ Jln. Urip Sumoharjo No. 5, Kota Makassar \\ rizkiramadani@umi.ac.id
}

Received: 19 Februari 2020; Accepted: 2 Apil 2020; Published: 29 Juni 2020

DOI: 10.20885/iustum.vol27.iss1.art9

\begin{abstract}
This study aims to determine the independency of Independent State Institutions (LNI) in Indonesia with the perspective of the concept of Independent Regulatory Agencies (IRAs). In addition, it also analyzes the LNI model that is in line with the concept of IRAs. The number of Independent State Institutions (LNI) in Indonesia has relatively increased since the amendment of the 1945 Constitution. However, the need for institutions that are free from government interference is not accompanied by the formulation of standards and mature institutional design on the aspect of independence as the main characteristic of LNI. This study uses a normative method, with statutory and conceptual approaches. This study concludes that the independence of LNI in Indonesia tends to be non-uniformed. Some institutions meet the aspects of formal independence in the concept of IRAs, but some others still have aspects of regulation that are incomplete. The results of the study of de facto independence also concluded that there were interventions, politicization and resistance from various parties towards the presence and policy of LNI in Indonesia. The LNI model that is in line with the IRAs concept can be done by improving 3 aspects: first, minimizing the authority of the DPR in the selection of LNI leaders, second, providing independent authority, and third, emphasizing the non-partisan provisions in each institutional regulation of $L N I$.
\end{abstract}

Keywords: Independence; independent regulatory agencies; LNI

Abstrak

Penelitian ini bertujuan untuk mengetahui independensi Lembaga Negara Independen (LNI) yang ada di Indonesia dengan perspektif konsep Independent Regulatory Agencies (IRAs). Di samping itu juga menganalisis model LNI yang sejalan dengan konsep IRAs. Jumlah lembaga negara independen (LNI) di Indonesia relatif meningkat sejak amendemen UUD 1945. Namun, kebutuhan atas lembaga yang bebas dari campur tangan pemerintah justru tidak disertai perumusan standar dan desain kelembagaan yang matang pada aspek independensi sebagai ciri utama LNI. Penelitian ini menggunakan metode normatif, dengan pendekatan perundang-undangan dan konseptual. Penelitian ini menyimpulkan bahwa independensi LNI di Indonesia cenderung tidak seragam. Beberapa lembaga memenuhi aspek independensi formal dalam konsep IRAs, namun sebagian lain masih memiliki aspek pengaturan yang belum lengkap. Hasil kajian terhadap independensi de facto juga menyimpulkan adanya intervensi, politisasi dan resistensi dari berbagai pihak terhadap kehadiran dan kebijakan LNI di Indonesia. Model LNI yang sejalan dengan konsep IRAs dapat dilakukan dengan memperbaiki 3 aspek: pertama, meminimalisir kewenangan DPR dalam pemilihan pimpinan LNI, kedua, memberikan kewenangan yang bersifat mandiri, dan ketiga, menegaskan ketentuan non-partisan dalam setiap aturan kelembagaan LNI.

Kata-kata Kunci: Independensi; independent regulatory agencies; LNI

${ }^{1}$ Penelitian ini merupakan hasil penelitian tesis pada Program Magister Fakultas Hukum UGM 


\section{Pendahuluan}

Penataan dan fungsi organisasi dalam bidang Kerjasama Ekonomi dan sektor publik Pembangunan (OECD) sejak era 1980-an telah mengalami pergeseran yang besar. Salah satu tren yang paling dominan dalam organisasi publik di negara-negara OECD adalah pergeseran dari urusan publik yang terpusat dan terkonsolidasi, menuju ke urusan publik yang terdesentralisasi dan bersifat otonom. Sistem administrasi publik kemudian dipisah dan dipencarkan menjadi berbagai jenis organisasi otonom, atau institusi yang independen, yang biasa diistilahkan sebagai 'Independent regulatory agencies/bodies' atau Lembaga negara Independen (LNI). ${ }^{2}$ Lembaga sejenis ini antara lain seperti Federal Trade Commision di Amerika Serikat, Commission des Operations de Bourse di Italia, atau The Commissions for Racial Equality di Inggris. ${ }^{3}$

Perkembangan model kelembagaan negara tersebut juga terjadi di Indonesia. Melalui amandemen konstitusi, format penyusunan lembaga negara kemudian lebih diarahkan untuk menyesuaikan dengan aspirasi rakyat dan kebutuhan perkembangan zaman. Trauma panjang akan otoritarianisme dan absolutisme menyebabkan model kelembagaan negara disusun sedemikian rupa secara terpisah dan setara sehingga dapat saling mengimbangi dan mengawasi. Seiring waktu, tuntutan akan perbaikan pelayanan, transparansi, dan akuntabilitas pihak penyelenggara negara juga terus menguat sehingga mendorong adanya reformasi institusi negara. ${ }^{4}$

Tren kelembagaan negara pasca amandemen kemudian mengarah pada terbentuknya lembaga-lembaga negara baru yang diidealkan memiliki karakteristik yang independen. Seperti Komisi Pemilihan Umum (KPU), Komisi Pemberantasan Korupsi (KPK), Komisi Nasional HAM (Komnas HAM), Komisi

${ }^{2}$ Koen Verhoest, et. all, Autonomy and Control of State Agencies,Comparing State Agencies, Palgrave Macmillan, United Kingdom, 2010, hlm. 3.

${ }^{3}$ Lihat Jimly Asshiddiqie, Pengantar Ilmu Hukum Tata Negara, Rajawali Press, Jakarta, 2013, hlm. 339-340.

4 Menurut Didik Supriyanto, reformasi institusi ini dilakukan dengan tujuan: pertama, memperkuat kedudukan dan fungsi lembaga legislatif dan yudikatif; kedua, membatasi dan mengurangi kekuasaan eksekutif. Selengkapnya Lihat Didik Supriyanto, "Menjaga Independensi Penyelenggara Pemilu", Hasil Penelitian Kerjasama USAID, drsp dan Perludem, hlm. 16. Tuntutan akan perbaikan pelayanan dan transparansi pemerintah misalnya, telah melahirkan lembaga seperti Komisi Ombudsman dan Komisi Informasi, sedangkan LNI dibidang judicial oversight seperti Komisi Yudisial dibentuk untuk merespon tuntutan akan akuntabilitas dan reformasi di tubuh kekuasaan kehakiman. 
Pengawas Persaingan Usaha (KPPU), Otoritas Jasa Keuangan (OJK) dan lain sebagainya. Pembentukan lembaga-lembaga negara baru dalam konteks transisi demokrasi di Indonesia ini pada dasarnya menjadi kelaziman berdasarkan semakin tingginya tuntutan dari masyarakat sipil (baik nasional maupun global) terhadap struktur ketatanegaraan yang "diharuskan" memerhatikan konsepkonsep atau ide-ide mengenai hak asasi manusia dan demokrasi. ${ }^{5}$

Eksistensi LNI bermula dari kehendak negara untuk membuat lembaga negara baru yang pengisian anggotanya diambil dari unsur non-negara, diberi otoritas negara, dan dibiayai oleh negara tanpa harus menjadi pegawai negara. ${ }^{6}$ Pembentukan lembaga-lembaga independen ini dapat dikatakan hanya cenderung bersifat reaksioner, sehingga menjadi tidak jelas kedudukan dan marwahnya dalam sistem ketatanegaraan. ${ }^{7}$ Bahkan tidak dipungkiri bahwa LNI di Indonesia terkadang dibentuk untuk alasan pencitraan rezim saja, dan dalam proses yang terburu-buru. ${ }^{8}$

Komisi Pemberantasan Korupsi (KPK) misalnya, adalah lembaga negara yang dalam melaksanakan tugas dan wewenangnya bersifat independen dan bebas dari pengaruh kekuasaan manapun. Namun jika membaca UndangUndang No. 30 Tahun 2002 tentang Komisi Pemberantasan Tindak Pidana Korupsi, maupun dalam Undang-Undang No. 19 Tahun 2019 tentang Perubahan Atas Undang-Undang No. 30 Tahun 2002 tentang Komisi Pemberantasan Tindak Pidana Korupsi, tidak ditemukan penjelasan mengenai maksud independensi. Faktanya, ketika KPK menerjemahkan kata 'independen' dalam wujud tindakan nyata pengusutan beragam kasus korupsi, masih timbul kontroversi di berbagai

${ }^{5}$ Luh Gede Mega Kharisma dan I Gede Putra Ariana, Kedudukan Komnas HAM sebagai Lembaga Negara Independen Dalam Sistem Ketatanegaraan Indonesia, Jumal Kertha Negara, Vol. 4, No. 5, Juli 2016, hlm. 3.

${ }_{6}^{6}$ Bunyamin Alamsyah dan Uu Nurul Huda, Politik Hukum Pelembagaan Komisi-Komisi Negara Dalam Sistem Ketatanegaraan Indonesia , Jurnal Hukum dan Peradilan, Volume 2, No. 1, Maret 2013, hlm. 94.

${ }^{7}$ Gunawan A. Tauda, Kedudukan Komisi negara Independen dalam Struktur Ketatanegaraan Indonesia, Jurnal Pranata Hukum, Vol. 6 No. 2, Juli 2011. hlm. 173.

8 Lebih lanjut lihat Zainal A. Mochtar, Penataan Lembaga Negara Independen Setelah Perubahan Undang-Undang Dasar 1945”, disertasi pada Sekolah Pascasarjana Univeristas Gadjah Mada Yogyakarta, 2012, hlm. 214-230. 
kalangan. Misalnya saja, KPK sering dianggap arogan dan menyalahgunakan kekuasaannya, ${ }^{9}$ bahkan eksistensinya dinilai dapat menghambat laju investasi. ${ }^{10}$

Ketidakjelasan independensi juga masih menjadi problem sentral yang menimpa LNI seperti Komisi Nasional Hak Asasi Manusia (Komnas HAM). Meskipun Pasal 1 angka 7 UU No. 39 Tahun 1999 tentang Hak Asasi Manusia telah menyatakan secara formal Komnas HAM sebagai lembaga mandiri yang setingkat dengan lembaga negara yang lain. Namun hal tersebut sampai hari ini belum mampu menggeser persepsi Komnas HAM sebagai 'macan ompong', akibat masih banyaknya kekurangan dalam regulasi yang menjadi dasar pembentukannya dan minimnya kewenangan sebagai lembaga negara yang berciri independen. ${ }^{11}$

Konsep yang umum digunakan, seperti Independent Regulatory Agencies (IRAs) atau konsep kelembagaan LNI dalam kepustakaan barat dapat digunakan untuk mengetahui independensi LNI dalam konteks Indonesia. ${ }^{12}$ Selain itu, juga dikenal dengan istilah lain seperti Independent Commissions, ${ }^{13}$ self regulatory bodies, Independent Agencies ${ }^{14}$, "semi-autonomous agencies"15 dan sebagainya. Konsep tersebut dapat dijadikan suatu perspektif guna mengetahui independensi LNI yang ada di Indonesia, dan merumuskan gagasan mengenai model LNI yang lebih ideal di masa depan.

\section{Rumusan Masalah}

Berdasarkan uraian di atas, penelitian ini berangkat dari dua rumusan masalah: pertama, bagaimanakah kesesuaian independensi LNI di Indonesia

${ }^{9}$ Lihat misalnya "Arogansi KPK Harus Dihentikan”, https://www.jpnn.com/news/arogansikpk-harus-dihentikan. Lihat juga "Pengamat Anggap Revisi UU Perlu Supaya KPK Tak 'Membabi Buta"', https://www.cnnindonesia.com/nasional/20190915164859-12-430657/pengamat-anggaprevisi-uu-perlu-supaya-kpk-tak-membabi-buta. diakses pada 10 Maret 2019.

10 "Moeldoko: KPK Bisa Hambat Investasi",https://bisnis.tempo.co/read/1251471/ moeldoko-kpk-bisa-hambat-investasi, diakses pada 10 Maret 2019.

11 Hal ini pernah diakui sendiri oleh komisioner Komnas HAM, http://www.hukumonline.com/berita/baca/lt4f7d11402f7ae/komnas-ham-butuhpenguatan-

kewenangan lihat juga "Komnas Ham Perlu Didesain Ulang", https://www.aji.or.id/read/berita/686/ komnas-ham-perlu-didesain-ulang.html diakses pada 10 Maret 2019.

${ }^{12}$ Fabrizio Gillardi, Delegation In The Regulatory State, Independent Regulatory Agencies In Western Europe, Edward Elgar Publishing Limited, United Kingdom, 2008, hlm. 13.

${ }^{13}$ Yves Meny dan Andrew Knapp, Government and Politic in Western Eruope: Britain, France, Italy, Germany, $3^{\text {rd }}$ Edition, Oxford University Press, Oxford, 1998, hlm. 281

${ }^{14}$ Neal Devins dan David E. Lewis, "Not-So Independent Agencies: Party Polarization and The Limits Of Institutional Design", Boston University Law Review, Vol. 88, 2008, hlm. 460.

${ }^{15}$ Niegel Bowles, Government and Politics of The United States, Macmillan Press, England, 1998, hlm. 250. 
dengan Konsep Independent regulatory agencies? Kedua, bagaimanakah model LNI di Indonesia yang sejalan dengan konsep Independent regulatory agencies?

\section{Tujuan Penelitian}

Penelitian ini bertujuan untuk mengetahui dua hal: pertama, bagaimana independensi lembaga negara independen di Indonesia ditinjau dalam perspektif independent regulatory agencies. Kedua, merumuskan gagasan optimalisasi bagi independensi lembaga negara independen dalam konteks Indonesia.

\section{Metode Penelitian}

Sebagai penelitian hukum, penelitian ini merupakan studi terhadap pengaturan lembaga-lembaga negara independen yang ada di Indonesia. Fokus utama dari penelitian ini adalah mengkaji dan menganalisis independensi LNI dalam regulasi pembentukannya dan pada aspek pelaksanaannya. Penelitian ini termasuk dalam jenis penelitian normatif. Ditinjau dari sifatnya, penelitian ini bersifat deskriptif-preskriptif dengan memadukan pendekatan undang-undang, dan konseptual. Penelitian ini memilih 12 LNI di Indonesia yang mengacu pada penelitian Bruce Ackerman yang menyimpulkan bahwa LNI yang paling banyak muncul di dunia berkaitan dengan; budget oversight, electoral, ombudsman, prosecutor, civil service, judicial oversight, dan anti corruption. ${ }^{16}$ Penelitian Ackerman termasuk yang cukup komprehensif dengan generalisasi terhadap fenomena LNI di hampir seluruh dunia. Beberapa penelitian lain seperti Giraudi, Gillardi dan Funk \& Seamon hanya fokus pada regional eropa atau Amerika Serikat secara umum. Jika dikaitkan dengan konteks Indonesia, maka lembaga independen yang dimaksud adalah Badan Pemeriksa Keuangan (BPK), Komisi Pemilihan Umum (KPU), Ombudsman RI, Komisi Kejaksaan, Komisi Yudisial (KY) dan Komisi Pemberantasan Korupsi (KPK). Mencermati isu dan tren kelembagaan yang ada, penulis juga memasukkan lima lembaga lain yakni: Komisi Polisi Nasional (Kompolnas) di bidang pengawasan penegak hukum, Bank Indonesia (BI) di bidang Perbankan, Komisi Pengawas Persaingan Usaha (KPPU) dan Otoritas Jasa Keuangan (OJK) dalam bidang

${ }^{16}$ Lihat John M. Ackerman, "Independent Accountability Agencies and Democracy: A New Separation of Powers?" paper on Workshop on Comparative Administrative Law, yale University, May 8-9 2009, hlm. 13. 
pengawasan ekonomi dan lembaga keuangan, serta Komisi Penyiaran Indonesia (KPI) dalam bidang pengawasan Media Siar.

\section{Hasil Penelitian dan Pembahasan}

\section{Kesesuaian Independensi LNI di Indonesia dengan Konsep Independent Regulatory Agencies}

Istilah LNI dalam konteks Indonesia jika dibandingkan dengan Amerika Serikat, dapat dikatakan tidak memiliki justifikasi yuridis yang berarti. Hal ini disebabkan sampai hari ini belum ada satu pun pasal dalam peraturan perundangundangan yang mencantumkan secara definitif istilah "lembaga negara independen". Ketika perumusan awal UUD 1945, LNI belum menemukan tempat pembicaraan dalam format ketatanegaraan. Bahkan istilah lembaga negara sendiri sama sekali belum dibicarakan. ${ }^{17}$ Legitimasi bagi pembentukan lembaga negara independen baru mendapatkan sentimen cukup baik pasca-perubahan UUD 1945. ${ }^{18}$

Hal sebaliknya dapat ditemukan di Amerika Serikat, yang lembaga negara independen atau biasa disebut Independent Regulatory Agencies (IRAs) benar-benar diatur dalam peraturan perundang-undangan secara limitatif. Hal ini sebagaimana terdapat dalam ketentuan The Paperwork Reduction Act 44 (U.S.C. $\S$ 3502), yang pada poin (5) menyatakan:

"The term "independent regulatory agency" means the Board of Governors of the Federal Reserve System, the Commodity Futures Trading Commission, the Consumer Product Safety Commission, the Federal Communications Commission, the Federal Deposit Insurance Corporation, the Federal Energy Regulatory Commission, the Federal Housing Finance Agency, the Federal Maritime Commission, the Federal Trade Commission, the Interstate Commerce Commission, the Mine Enforcement Safety and Health Review Commission, the National Labor Relations Board, the Nuclear Regulatory Commission, the Occupational Safety and Health Review Commission, the Postal Regulatory Commission, the Securities and Exchange Commission, the Bureau of Consumer Financial Protection, the Office of Financial Research, Office of the Comptroller of the Currency, and any other similar agency designated by statute as a Federal independent regulatory agency or commission". ${ }^{19}$

17 Zainal Arifin Mochtar, Lembaga Negara Independen: Dinamika Perkembangan dan Urgensi Penataannya Kembali Pasca-Amandemen Konstitusi, Rajawali Pers, Jakarta, 2016, hlm. 5.

${ }^{18}$ Ibid., hlm. 4-6.

19 “The Paperwork of Reduction Act of 1980". Dikutip dari laman https://www.law.cornell.edu/ uscode/text/44/3502 Peraturan ini pada intinya dibuat untuk meringankan beban pekerjaan administratif lembaga pemerintah di sektor privat, dengan mendelegasikan sebagaian kewenangan tersebut kepada lembaga-lembaga di luar eksekutif. Secara keseluruhan peraturan ini memuat persyaratan prosedural bagi 
Berdasarkan ketentuan tersebut, dapat diketahui secara langsung bahwa setidaknya terdapat sembilan belas lembaga negara yang secara eksplisit ditentukan sebagai lembaga negara independen atau IRAs, di samping lembaga lain dengan karakteristik sejenis yang ditentukan oleh undang-undang. Dengan demikian, terdapat semacam role model atau blue print, dimana para analis dapat mengkaji dan merumuskan karakteristik khusus dari lembaga-lembaga yang disebutkan, sehingga didapatkan kriteria atau standar umum Independent Regulatory Agencies dalam konteks Amerika Serikat. ${ }^{20}$ Secara a contrario, maka lembaga lain yang tidak termasuk dalam ketentuan tersebut atau karakteristik kelembagaannya tidak sepenuhnya sama, maka dikualifikasi tidak termasuk dalam kategori IRAs.

Curtis W. Copeland mencontohkan dengan Environmental Protection Agency (EPA) yang merupakan lembaga independen (independent agencies) di Amerika dan berada di luar struktur eksekutif, namun tidak tercantum dalam ketentuan The Paperwork Reduction Act sebagai IRAs. Satu hal yang membuat EPA hanya dikategorikan sebagai "independent agencies" dan bukan "independent regulatory agencies" atau IRAs adalah tidak adanya independensi EPA dalam hal pemberhentian pimpinannya oleh Presiden. ${ }^{21}$ Copeland menyatakan bahwa Independent Agencies tidak termasuk golongan IRAs, disebabkan perbedaan derajat independensinya, terutama pada aspek political independence, yang mencirikan adanya jarak dari kontrol dan pengaruh presiden. ${ }^{22}$ Independent Agencies cenderung lebih terbuka dengan pengaruh presiden, dimana lembaga ini dibentuk atas dasar "to serve the pleasure of the president". Namun demikian, Independent agencies juga tidak dapat dikategorikan sebagai executive agencies atau lembaga sejenis kementerian dan departemen, sebab lembaga ini tidak termasuk dalam struktur kekuasaan eksekutif. Berdasarkan pandangan ini dapat disimpulkan bila Independent agencies pada

lembaga-lembaga tersebut dalam menajalankan kewenangannya. Lihat https://en.wikipedia.org/ wiki/Paperwork Reduction Act

${ }^{20}$ Rizki Ramadani \& Moch. Andry WW.M, The Independency of the Corruption Eradication Commission of the Republic of Indonesia (KPK RI) in Indicators of Independent Regulatory Agencies (IRAs), Substantive Justice International Journal of Law, Vol. 1, Issue 2., Juli 2018, hlm. 84.

${ }^{21}$ Curtis W. Copeland, "Economic Analysis and Independent Regulatory Agencies", draft Report for the consideration of the administrative conference of United States, US A., 2013, hlm. 6.

${ }^{22}$ Curtis W. Copeland, Op. Cit., hlm. 6. 
dasarnya adalah lembaga pemerintah yang bersifat independen, namun bukan dalam kategori lembaga negara independen yang sebenarnya.

Fenomena yang mirip juga ditemukan oleh Giorgio C.S Giraudi saat mengidentifikasi eksistensi IRAs yang ada di Perancis. Giraudi menemukan ada dua model IRAs yang terbentuk: Pertama, terdapat sejumlah komisi dengan kewenangan yang bersifat advisory, dan memiliki banyak anggota (komisioner). Ide mendasar dari pembentukan IRAs ini adalah "Comission of independent sages" ${ }^{23}$ Komisi ini bertugas memberikan saran dan usulan kepada parlemen dan pemerintah. Kedua, terdapat juga IRAs dengan karakteristik jumlah anggota yang sedikit, biasanya dipilih oleh presiden dan parlemen. Pada model yang kedua ini, IRAs memiliki kewenangan yang dikatakannya sebagai "normally fully regulatory" mencakup kewenangan rulemaking, pengawasan, supervisi, penjatuhan sanksi dan yang berkaitan dengan peradilan. Fenomena yang tidak jauh berbeda juga ditemukan pada konsep IRAs di Italia, $^{24}$ misalnya Commisione Nazionale per le Societa E la Borza (CONSOB) yang merupakan lembaga independen dalam rangka pengawasan terhadap kinerja stock Exchange. Kewenangan pengawasan mencakup pengaturan dibidang investasi dan penegakan sanksi terhadap para pihak yang melanggar aturan tersebut.

Thatcher yang menganalisis fenomena IRAs di Inggris, Prancis, Jerman dan Italia, menarik konklusi bahwa ada tiga aspek yang paling penting dari IRAs, yakni independensinya dari pejabat-pejabat terpilih (elected officials), hubungan dengan lembaga administratif lain (regulatees), dan proses pengambilan keputusannya. Thatcher lalu menjabarkan bahwa independensi IRAs dalam praktiknya dapat dilihat dari lima indikator.

1. Party Politicisation of appoinments, yakni sejauhmana terjadi politisasi dalam penentuan pimpinan IRAs, 2. Departures (dismissal and resignation), yakni pemberhentian anggota IRAs sebelum berakhirnya masa jabatan, 3 . The Tenure of IRA members, semakin lama masa jabatannya, maka semakin besar independensinya terhadap pejabat-pejabat terpilih. 4. The financial and Staffing resources of IRA, yakni independensi dalam hal keuangan dan manajemen sumber daya. 5. The use of power to overturn the decisions of IRAs by elected politicians,

${ }^{23}$ Lihat Giorgio C.S. Giraudi, "Independent Regulatory Agencies in Italy and France, Building The Bridge between delegation and Europanization", Swiss Political Science Review, Vol. 8, 2002, hlm. 112.

${ }^{24}$ Giraudi, Ibid. 
yang dimaknai sebagai penggunaan kekuasaan untuk menganulir keputusan/kebijakan yang dikeluarkan IRAs ${ }^{25}$

Di samping karakteristik kelembagaan, independensi juga termanifestasi pada karakteristik kewenangan yang dimiliki oleh LNI. Di Amerika, banyak terdapat badan-badan pemerintah federal yang diberikan kewenangan secara konstitusional oleh lembaga legislatif (melalui undang-undang) untuk menjalankan kekuasaan secara independen. Sebagaimana dikemukakan oleh Funk dan Seamon, badanbadan federal ini secara praktis menjalankan fungsi-fungsi pemerintahan dengan mengkombinasikan kekuasaan legislatif, eksekutif dan yudikatif atau kekuasaan yang bersifat kuasi. ${ }^{26}$ Sudah jamak diketahui pula jika lembaga yang tergolong dalam IRAs di negara-negara Amerika maupun Eropa memiliki kewenangan yang berciri self-regulatory atau rule making ${ }^{27}$, yakni semacam otonomi yang diberikan untuk membuat peraturan kelembagaan sendiri secara mandiri.

Berdasarkan beberapa konsep IRAs yang digagas oleh para pakar di atas, maka penulis bermaksud untuk mengintegrasikan berbagai pandangan tersebut guna meninjau LNI di Indonesia. Adapun indikator independensi yang digunakan terbagi atas independensi formal dengan melihat aspek pengaturan dalam undang-undang, dan independensi de facto dengan melihat aspek pelaksanaan atau resistensi terhadap LNI ketika melaksanakan kewenangannya. Analisis dilakukan dengan memadukan pandangan dari Mark Thatcher tentang indikator LNI dan Wiliam F. Funk tentang jenis kewenangan LNI yang bersifat kuasi.

Berdasarkan tinjauan dalam konsep IRAs, sejumlah LNI di Indonesia seperti Komisi Yudisial, Ombudsman, Otoritas Jasa Keuangan, Bank Indonesia, Komisi Penyiaran Indonesia dan Komisi Pemilihan Umum memiliki pengaturan independensi yang sangat baik dari segi formal. Dasar hukum pembentukannya sudah cukup memuat berbagai aspek yang diperlukan baik secara personalia, fungsional maupun institusional. Secara formal kelembagaan, lembaga-lembaga ini dapat dikatakan memiliki independensi yang besar. Dengan demikian sudah

\footnotetext{
${ }^{25}$ Mark Thatcher, "Independent regulatory agencies in Europe", Risk and Regulation Magazine, Summer 2005, 2011, hlm. 117.

${ }^{26}$ William F. Funk dan Robert H. Seamon, Admisnistrative Law: Examples and Explanations, Apen Law \& Bussiness, Printed in the United States of America, New York., 2001, hlm. 23-24.

${ }^{27}$ Fabrizio Gillardi, 2008, Delegation In..., Op. Cit., hlm. 22.
} 
memenuhi seluruh kriteria IRAs. Berikut adalah contoh hasil analisis terhadap independensi formal lembaga Komisi Yudisial yang menurut hasil kajian penulis merepresentasikan independensi yang cukup ideal dari segi pengaturan kelembagaannya:

Tabel 1. Independesi Formal KY

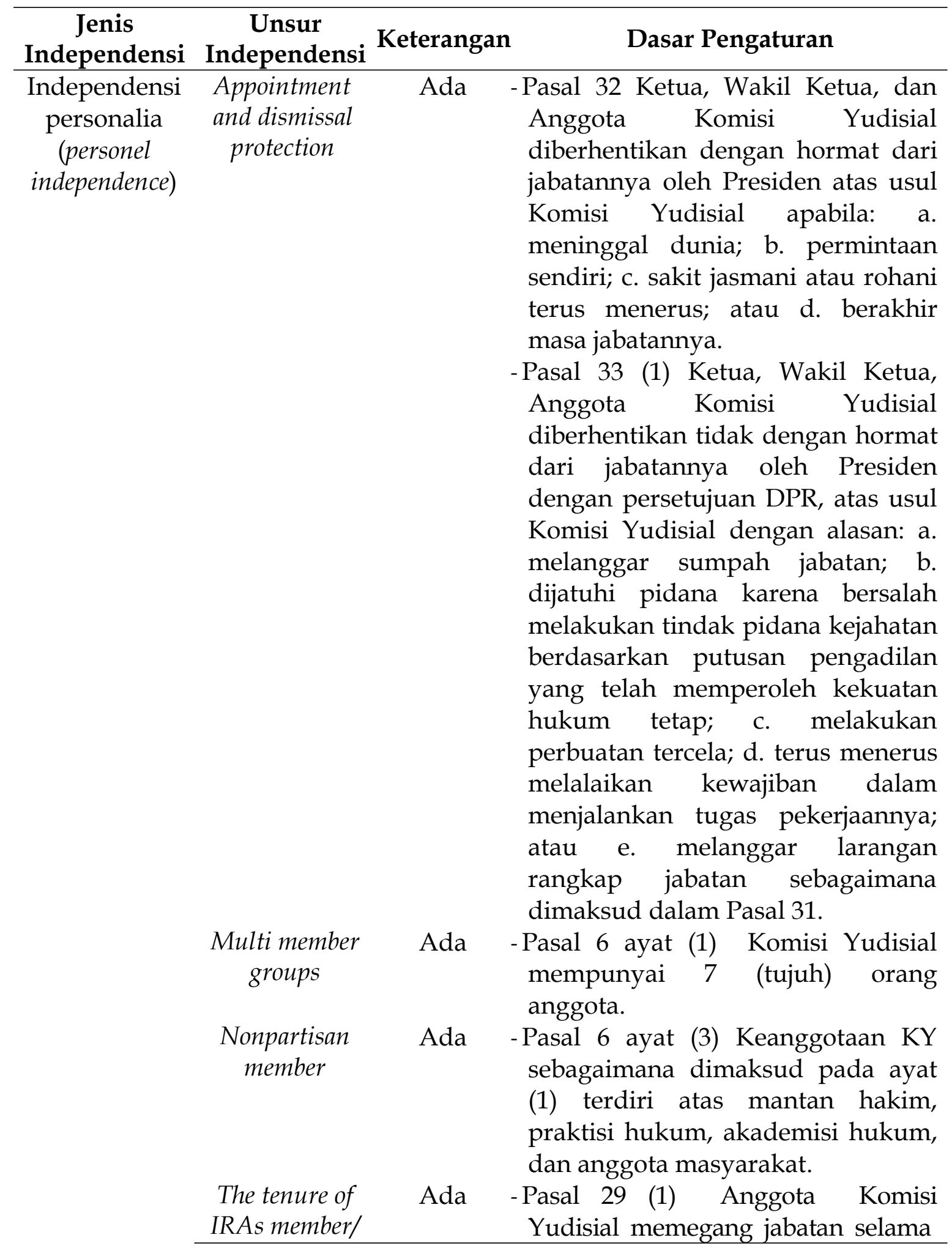




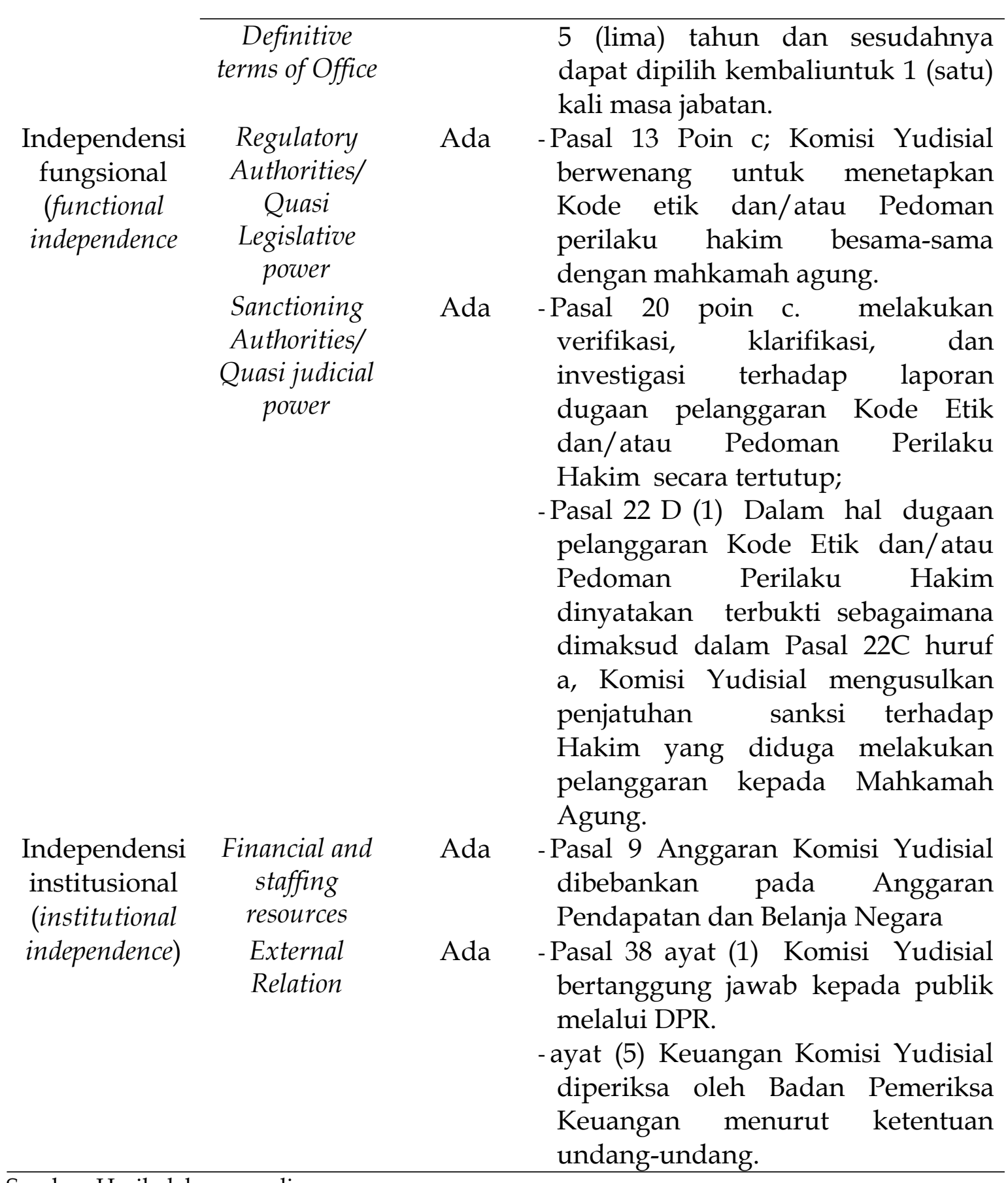


Beberapa lembaga lain seperti Komisi Pemberantasan Korupsi (KPK) ${ }^{28}$ dan Komnas HAM, dan BPK bisa dikatakan sebagai golongan lembaga dengan independensi yang cukup, sebab beberapa aspek independensinya masih ada yang kurang atau perlu disempurnakan. Misalnya ketiadaaan kewenangan yang bersifat kuasi yudisial di tubuh Komnas HAM yang dapat menunjang independensinya dalam mengusut kasus-kasus pelanggaran HAM. Serta keberadaan organ Dewan Pengawas dengan kewenangan otorisasi yang berpotensi mereduksi kewenangan komisioner dan menyulitkan kerja-kerja penyidik KPK. Dalam konteks BPK, celah independensi misalnya terletak pada absennya ketentuan dan larangan soal anggota yang nonpartisan, dimana hal ini dapat membuka pintu yang lebar bagi penguasaan BPK oleh DPR. Faktanya dalam pemilihan di 2014, terpilih politikus dari Partai Golkar Harry Azhar Aziz, politikus dari Partai Demokrat Achsanul Qosasi, serta Ketua BPK saat itu Rizal Djalil yang juga merupakan legislator DPR dari fraksi Partai Amanat Nasional. Komposisi anggota yang demikian dalam pandangan ICW, membuat lembaga ini akan sulit menghindari benturan kepentingan dalam audit BPK. ${ }^{29}$

Lembaga lainnya seperti Komisi Polisi Nasional dan Komisi Kejaksaan, memiliki beberapa kekurangan yang mendasar dalam pengaturannya sehingga belum cukup untuk memenuhi indikator independensi IRAs. Khususnya pada aspek independensi dari kekuasaan eksekutif yang merupakan ciri utama dari IRAs. Dalam ketentuan hukum Kompolnas dan Komjak dinyatakan secara ekplisit bahwa keduanya bertanggung jawab dan berada di bawah Presiden. ${ }^{30}$ Aturan pembentukan Kompolnas dan Komisi Kejaksaan juga menentukan bahwa

${ }^{28}$ UU KPK yang baru tetap mempertahankan Pasal 3 bahwa KPK independen dan bebas dari campur tangan kekuasaan manapun. Apabila makna "bertanggung jawab" adalah kewajiban menyusun laporan pertanggung jawaban kepada Presiden dan DPR, maka hampir semua LNI diwajibkan untuk itu oleh UU sebagai bentuk transparansi dan akuntabilitas. Namun, tidak mengurangi independensi formal dan de facto seperti dalam Kompolnas dan Komisi kejaksaan,bahwa secara eksplisit keduanya diatur "bertanggung jawab dan berada di bawah" Presiden. Meskipun demikian, penulis tidak memungkiri adanya kemungkinan reduksi independensi KPK berdasarkan UU yang baru. Oleh karenanya, penulis mengkualifikasi KPK sebagai LNI dengan kategori cukup/sedang.

${ }^{29}$ Lihat "Politikus Kuasasi BPK, Independensi Terancam" https://m.tempo.co/read/news/ 2014/09/17/090607491/politikus-kuasai-bpk-independensi-terancam diakses pada 12 Juli 2016.

${ }^{30}$ Lihat misalnya Pasal 2 ayat (2) PERPRES No. 17 Tahun 2011 dan Pasal 2 ayat (2) PERPRES No. 18 Tahun 2011. 
tiga di antara komisionernya ditunjuk langsung oleh Presiden sebagai wakilnya. ${ }^{31}$ Dalam konteks Komisi Kejaksaan, ketua dan wakil ketua juga dipilih oleh presiden. Lembaga-lembaga ini dapat dikatakan sebagai golongan dengan independensi yang kecil. Dengan demikian belum mampu menunjang independensinya secara de facto.

Hasil tinjauan terhadap aspek independensi de facto, pada kriteria party politication of appointment menunjukkan LNI menghadapi kendala besar disebabkan oleh mekanisme pemilihan oleh Dewan Perwakilan Rakyat (DPR). Mayoritas pemilihan komisioner LNI yang melibatkan DPR berujung pada politisasi. ${ }^{32}$ Berdasarkan analisis terhadap independensi de facto, politisasi oleh DPR terjadi hampir dalam setiap LNI, terkecuali Komisi Polisi Nasional dan Komisi Kejaksaan yang dalam mekanisme pemilihannya menurut Perpres memang tidak melibatkan DPR, namun selesai di tangan pansel dan presiden. ${ }^{33}$ Sebelum Pasal 28 ayat (3) huruf c, ayat (6) dan Pasal 37 UU Nomor 18 Tahun 2011 tentang Komisi Yudisial digugat oleh masyarakat ke Mahkamah Konstitusi, KY pun mengalami hal yang serupa dimana DPR memiliki kewenangan untuk memilih calon komisioner.

Melalui indikator The use of power to overturn the decisions of IRAs, analisis de facto menunjukkan bahwa LNI di Indonesia cenderung mengalami intervensi, resistensi, atau perlawanan terhadap kebijakannya. Resistensi terhadap LNI bukan saja datang dari pihak pemerintah, namun juga oleh para pihak yang terkait dengan tugas dan kewenangannya. Seperti judicial reviewoleh 31 orang hakim agung terhadap UU Nomor 22 Tahun 2004 tentang Komisi Yudisial dalam perkara Nomor 005/PUU-IV/2006 tertanggal 23 Agustus 2006 ke Mahkamah Konstitusi. Putusan MK pada akhirnya memangkas beberapa kewenangan KY

${ }^{31}$ Selengkapnya Pasal 14 Perpres No. 17 Tahun 2011 mengatur keanggotaan Kompolnas terdiri dari unsur; a) Pemerintah sebanyak 3 (tiga) orang, b) Pakar Kepolisian sebanyak 3 (tiga) orang, dan c) Tokoh masyarakat sebanyak 3 (tiga) orang,

32 Politisasi secara umum diartikan sebagai hal yang membuat keadaan (perbuatan, gagasan, dan sebagainya) bersifat politis. Juga berarti membuat atau mengupayakan agar sesuatu sesuai dengan kepentingannya yang dimaksud. Lihat Rina Martini, "Politisasi birokrasi di Indonesia". POLITIKA Jurnal Ilmu Politik MIP, Vol. 1 No. 1, 2010, hlm. 70. Di sini politisasi juga mengacu pada Thatcher yang menyebutkan istilah "Party politicisation of appointment". Selanjutnya ia mengungkapkan "the greater the politicisastion of the regulators, the lower the likely independence, and the greater the control by elected officials". Selengkapnya lihat Mark Thatcher, "Independent regulatory agencies in Europe". Risk and Regulation Magazine, Summer2005, 2011, hlm. 117.

${ }^{33}$ Lihat misalnya Pasal 29 PERPRES No. 17 Tahun 2011 dan PERPRES No. 18 Tahun 2011. 
dalam lingkup pengawasan Hakim. ${ }^{34}$ Demikian pula dengan judicial review terhadap undang-undang yang melemahkan independensi Otoritas Jasa Keuangan. ${ }^{35}$

KPK mendapatkan resistensi yang cukup besar dari POLRI yang dibuktikan dengan konflik berkepenjangan antara "cicak vs buaya" dalam penanganan kasus korupsi simulator SIM. Termasuk sengketa kewenangan penyidikan dalam kasus Suap terhadap mantan kabareskrim polri, dan penetapan tersangka terhadap Komjen Budi Gunawan yang berujung pada penahanan terhadap dua komisioner KPK pada masa itu. Belum lagi sejumlah manuver politik oleh DPR dalam bentuk hak angket dan revisi UU KPK. Sedangkan dalam konteks Ombudsman, hampir tiga puluh persen instansi tidak menjalankan rekomendasi yang dikeluarkan Ombudsman, yang keseluruhannya ada sepuluh kementrian/lembaga sejak lima tahun terakhir. ${ }^{36}$

Pada 2014, terjadi pencopotan Ketua BPK Provinsi DKI Jakarta yang saat itu membeberkan indikasi kerugian negara sebesar Rp. 191.000.000.000,00 hingga Rp. 484.000.000.000,00 atas pembelian lahan RS Sumber Waras oleh Pemprov DKI di APBD-perubahan. Sedangkan KPU setidaknya beberapa kali mengalami overturn terhadap kebijakannya. Di antaranya gugatan Oesman Sapta Odang terhadap Peraturan KPU No. 20 Tahun 2018 tentang Pencalonan Anggota DPR dan DPRD Kabupaten/Kota yang berujung pada pembatalan beberapa Pasal dalam aturan tersebut oleh Mahkamah Agung. Juga pembatalan PKPU Pasal 60 huruf j PKPU No. 26 Tahun 2018 tentang Pencalonan Anggota DPD terkait penghapusan mantan narapidana kasus korupsi, bandar narkoba, kejahatan seksual terhadap anak, menjadi calon anggota legislatif pada Pemilu 2019. Secara umum dapat dilihat pada tabel di bawah ini.

\section{Tabel 2}

34 Lihat Putusan MK Nomor 005/PUU-IV/2006. Gusliana HB mengidentifikasi hilangnya kewenangan KY karena MK membatalkan delapan pasal. Pembatalan tersebut terkait dengan Pasal 1 angka (5) sepanjang kata-kata hakim konstitusi. Pasal 20, 21, Pasal 22 ayat (1) huruf e, Pasal 22 ayat (5), Pasal 23 ayat (2), (3), (5), Pasal 24 ayat (1), Pasal 25 ayat (3) UU Nomor 22 Tahun 2004, dan Pasal 24 ayat (3) UU Nomor 4 Tahun 2004 tentang Kekuasaan Kehakiman. Selengkapnya lihat Gusliana HB, "Komisi Yudisial Kini dan Mendatang Pasca putusan Mahkamah Konstitusi: Antara Harapan dan Kenyataan”, Jurnal Equality, Vol. 12 Nomor 2, 2007, hlm. 58.

${ }^{35}$ Lihat Putusan MK Nomor 25/PUU-XII/2014. Dalam putusannya MK menghilangkan frasa "yang bebas dari campur tangan kekuasaan manapun" dari Pasal 1 angka 1 UU No. 21 Tahun 2007 Tentang Otoritas Jasa Keuangan.

36 "10 Kementrian Disebut abaikan Rekomendasi Ombudsman" https://www.medcom.id/nasional/politik/nN9w02ek-10-kementerian-disebut-abaikan-rekomendasiombudsman diakses pada 12 April 2020 
Hasil Analisis Aspek "The use of power to overturn the decisions of IRAs"

\begin{tabular}{ll}
\hline \multicolumn{1}{c}{ Lembaga Negara Independen } & \multicolumn{1}{c}{ Sumber Resistensi } \\
\hline 1. Komisi Pemberantasan Korupsi (KPK) & $\begin{array}{l}\text { POLRI, DPR } \\
\text { Hakim MA dan MK }\end{array}$ \\
\hline 3. Komisi Yudisial (KY) & $\begin{array}{l}\text { TNI, Pemerintah (Presiden/DPR), } \\
\text { Kejaksaan Agung }\end{array}$ \\
4. Badan Pemeriksa Keuangan (BPK) & DPR, Presiden \\
5. Bank Indonesia (BI) & Pemerintah (Presiden/DPR) \\
6. Otoritas Jasa Keuangan (OJK) & Asosiasi Profesi \\
7. Komisi Penyiaran Indonesia (KPI) & Lembaga Penyiaran \\
8. Komisi Pemilihan Umum (KPU) & DPR \\
9. Komisi Polisi Nasional & Presiden, POLRI \\
10. Komisi Kejaksaan & Jaksa Agung \\
11. Komisi Pengawas Persaingan Usaha & Pelaku Usaha \\
(KPPU) & \\
12. Ombudsman & Pemerintah \\
\hline
\end{tabular}

Sumber: Hasil olahan penulis

Mengacu pada pandangan Curtis W. Copeland, yang telah disinggung sebelumnya dapat dikemukakan bahwa independensi LNI di Indonesia menunjukkan tidak semuanya berciri IRAs, tetapi ada pula yang hanya sebatas Independent Agencies saja. Hal ini sebagaimana fenomena kelembagaan yang terjadi di Amerika Serikat. Mengacu pada dikotomi lembaga negara independen ini, maka 12 lembaga negara yang diasumsikan independen di Indonesia dapat dibagi menjadi dua golongan (kecenderungan) sebagai berikut.

Tabel 2

Klasifikasi LNI berdasarkan Independensinya (Copeland)

\begin{tabular}{ll}
\hline \multicolumn{1}{c}{$\begin{array}{c}\text { Lembaga berjenis Independent } \\
\text { Regulatory Agencies (IRAs) }\end{array}$} & \multicolumn{1}{c}{$\begin{array}{c}\text { Lembaga berjenis Independent } \\
\text { Agencies }\end{array}$} \\
\hline Komisi Pemberantasan Korupsi (KPK) & Komisi Polisi Nasional \\
Komisi Yudisial (KY) & Komisi Kejaksaan \\
Komisi Nasional HAM & Komisi Pengawas Persaingan Usaha \\
Badan Pemeriksa Keuangan (BPK) & (KPPU) \\
Bank Indonesia (BI) & \\
Otoritas Jasa Keuangan (OJK) & \\
Komisi Penyiaran Indonesia (KPI) & \\
Komisi Pemilihan Umum (KPU) & \\
Ombudsman & \\
Sumber: Hasil olahan Penulis
\end{tabular}


Dari sebelas lembaga yang telah dianalisis, terdapat tiga lembaga negara yang belum cukup independensinya untuk dikategorikan sebagai IRAs, namun cenderung memenuhi konsep Independent Agencies. Alasan untuk mengategorikan Kompolnas dan Komjak sebagai Independent Agencies dan bukan IRas adalah disebabkan kedudukan keduanya yang subordinat atau inferior terhadap presiden. Dalam ketentuan hukum Kompolnas dan Komjak dinyatakan secara ekplisit bahwa keduanya bertanggung jawab dan berada di bawah Presiden. ${ }^{37}$ Komisi Kejaksaan sendiri meskipun dalam Pasal 2 ayat (1) dinyatakan sebagai lembaga nonstruktural yang dalam menjalankan tugas dan wewenangnya bersifat mandiri, tetap dipandang sebagai lembaga pemerintah seperti yang termaktub dalam ketentuan konsiderannya. ${ }^{38}$

Minimnya kewenangan baik dari segi regulatory (penetapan aturan tertentu) dan kewenangan quasi judicial (penyelidikan, penuntutan atau penjatuhan sanksi) membuat fungsi pengawasan ini terkesan mandul, sehingga predikat sebagai monitoring bodies kiranya menjadi kurang relevan.Usulan penjatuhan sanksi misalnya, dari kelembagaan Kompolnas hanya dapat direkomendasikan kepada Kapolri, sedangkan Komjak mesti menyampaikan usulan tersebut kepada jaksa Agung. ${ }^{39}$ Padahal, pada dasarnya kewenangan rekomendasi tidak memiliki kekuatan hukum mengikat, sehingga sangat minim kekuatan eksekutorialnya. Fungsi yang lebih menonjol dari kompolnas misalnya justru lebih pada aspek advisory atau memberi masukan kepada Presiden. ${ }^{40}$

${ }^{37}$ Pasal 2 ayat (2) PERPRES No. 17 Tahun 2011 dan Pasal 2 ayat (2) PERPRES No. 18 Tahun 2011.

${ }^{38}$ Pasal 1 angka 2 menyatakan Kejaksaan Republik Indonesia yang selanjutnya disebut Kejaksaan adalah lembaga pemerintahan sebagaimana dimaksud dalam Pasal 2 ayat (1) UndangUndang Nomor 16 Tahun 2004 tentang Kejaksaan Republik Indonesia.

39 Pasal 9 huruf e. PERPRES No. 17 Tahun 2011 menyatakan kompolnas dapat merekomendasikan kepada Kapolri, agar anggota dan/atau pejabat Polri yang melakukan pelanggaran disiplin, etika profesi dan/atau diduga melakukan tindak pidana, diproses sesuai dengan ketentuan peraturan perundang-undangan yang berlaku. Sedangkan dalam Pasal 9 PERPRES No. 18 Tahun 2011, dinyatakan bahwa Dalam melaksanakan tugas dan wewenangnya, Komisi Kejaksaan dapat menyampaikan rekomendasi yang salah satunya berupa pemberian sanksi terhadap Jaksa dan/atau pegawai Kejaksaan sesuai dengan pelanggaran yang dilakukan. Dalam Pasal lain yakni Pasal 7 ayat (1) dinyatakan bahwa Hasil pemeriksaan dan temuan Komisi Kejaksaan disampaikan dalam bentuk rekomendasi kepada Jaksa Agung untuk ditindaklanjuti.

40 Pasal 4 PERPRES No. 17 Tahun 2011 menyatakan Kompolnas bertugas : a. membantu Presiden dalam menetapkan arah kebijakan Polri; dan b. memberikan pertimbangan kepada Presiden dalam pengangkatan dan pemberhentian Kapolri. 
Perihal Komisi Pengawas Persaingan Usaha (KPPU), kesesuaian dengan konsep Independent agencies lebih didasarkan pada minimnya independensi dalam aspek personalia. Ketentuan mengenai sebab-sebab pemberhentian komisioner KPPU, salah satunya terdapat frasa "diberhentikan". ${ }^{41}$ Ada perbedaan antara mekanisme pemberhentian/removal /resignation dengan frasa "diberhentikan". Untuk konteks lembaga pemerintah semacam departemen dan kementrian, mekanisme diberhentikan merupakan hal yang umum. Sebagaimana menteri adalah jabatan politis yang menjadi hak prerogatif presiden. Namun dalam konteks LNI merupakan hal yang tidak lazim, sebab perlu ada independensi personalia, fungsional dan institusional untuk melindungi pimpinan dari ancaman pemberhentian tanpa sebab yang jelas. Dalam konteks LNI, pemberhentian lazimnya disebabkan oleh alasan yang jelas dalam undangundang seperti meninggal dunia, sakit, melakukan tindak pidana.

Hal ini mengindikasikan bahwa terlepas dari beberapa alasan pemberhentian sebelumnya yang ditentukan secara definitif seperti meninggal dunia atau mengundurkan diri, tetap ada kewenangan Presiden untuk memberhentikan anggota KPPU tanpa sebab yang diatur secara jelas. Dengan demikian ketentuan ini masih membuka kemungkinan untuk dapat memberhentikan sesuai dengan alasan subyektif presiden.

Gambar 1

Kedudukan LNI berdasarkan Independensinya

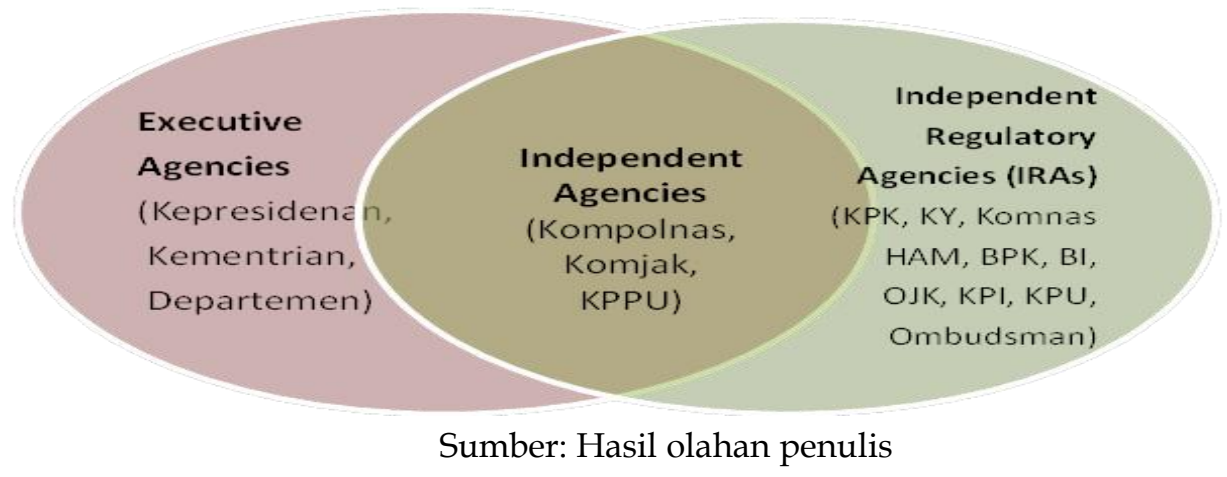

Persepsi di atas menunjukkan secara jelas posisi 12 lembaga negara yang telah dikaji diperhadapkan dengan posisi lembaga eksekutif. Sebagimana dietahui bahwa lembaga eksekutif merupakan lembaga pemerintahan yang

${ }^{41}$ Pasal 33 UU No. 5 Tahun 1999 tentang Larangan Monopoli dan Persaingan Usaha Tidak Sehat 
bekerja untuk kepentingan pemerintah. Baik Kompolnas, Komisi Kejaksaan, maupun KPPU berdasarkan hasil analisis terhadap independensinya, masih berada pada irisan antara lembaga eksekutif dan IRAs. Dengan kata lain, ketiga lembaga tersebut tidak sepenuhnya independen untuk bisa dikategorikan sebagai LNI/IRAs. Ketiganya masih pada derajat lembaga eksekutif yang independen atau dalam bahasa Copeland disebut dengan Independent agencies.

Penyempurnaan Model LNI di Indonesia yang sejalan dengan Konsep Independent Regulatory Agencies

\section{a. Minimalisasi kewenangan DPR dalam memilih pimpinan LNI}

Praktik pasca amandemen menunjukkan semakin besarnya pengaruh dan kewenangan DPR, salah satu yang sangat menonjol, dapat dilacak dari model pengisian sejumlah jabatan negara yang terbilang strategis. Misalnya, Pasal 16 ayat (2) UUD 1945 menyatakan dalam hal mengangkat duta, presiden memperhatikan pertimbangan DPR. Kekuasaan DPR-pun jauh melebar hingga pengisian komisi-komisi yang tidak disebut di dalam UUD NRI Tahun 1945 dan hakikat pendiriannya pun bersifat independen. Pengertian the right to confirm dalam praktik di Indonesia cenderung sudah menyimpang. Fungsinya yang politik berubah menjadi sangat teknis. Pada kenyataannya, the right to confirm tersebut berkembang menjacli the right to elect, atau lebih teknis lagi the right to select, dan bahkan the right to test. ${ }^{42}$

Berdasarkan hasil penelusuran terhadap independensi formal LNI di Indonesia, dari sebelas lembaga negara yang dikaji hanya terdapat dua lembaga yang pemilihan anggota atau komisionernya tidak melibatkan DPR. Kedua lembaga tersebut adalah Komisi Kejaksaan dan Kompolnas, yang memang peraturan kelembagaannya menetapkan Presiden sebagai pemegang hak penuh dalam pengangkatan komisionernya.

Mengacu pada hal di atas, maka salah satu format independensi yang ideal bagi LNI di Indonesia adalah dengan cara: pertama, memberikan kewenangan pada Presiden untuk membentuk panitia Seleksi yang independen dan representatif berimbang. Pansel yang independen dan representatif hanya dapat dihasilkan dari

${ }^{42}$ Susana Rita Susana Rita, “Meninjau Ulang Seleksi Pejabat Publik”, Opini pada Harian Kompas, 15 Oktober 2014. 
proses pembentukan yang transparan dan akuntabel. Untuk itu, sedari penentuan komposisi pansel sudah harus melibatkan partisipasi masyarakat, termasuk memperhatikan setiap laporan dan pengaduan masyarakat terkait track record calon anggota pansel. Cara terbaik dalam hal ini adalah pembentukan pansel tidak diinisiasi oleh pemerintah, tetapi oleh LNI yang bersangkutan dengan partisipasi publik. Kedua, tim seleksi memilih calon anggota sesuai dengan jumlah anggota yang dibutuhkan, untuk kemudian mendapatkan pengesahan presiden dan diajukan kepada DPR. Ketiga, dengan demikian DPR tidak perlu lagi melakukan fit and proper test dalam rangka memilih calon, namun langsung menggunakan haknya untuk menyatakan setuju atau tidak setuju (right to confirm) pada calon anggota yang diajukan, keempat, untuk menjamin efektivitas dan efisiensi, penolakan atau ketidaksetujuan disertai dengan alasan yang jelas dan dilakukan paling banyak satu kali.

\section{b. Pemberian kewenangan yang bersifat mandiri}

Berdasarkan hasil tinjauan, kewenangan yang dimiliki oleh beberapa LNI masih sangat kurang sehingga belum mampu menunjang eksistensi LNI secara de facto. Kekurangan ini pada akhirnya menjadi kendala bagi lembaga yang bersangkutan dan memengaruhi hasil kinerjanya. Komisi Pemberantasan Korupsi (KPK) belum diberikan kewenangan untuk merekrut penyidik independen, melainkan hanya meminjam penyidik dari instansi lain. ${ }^{43}$ Hal ini tentu bukan tanpa konsekuensi negatif. Konflik antara KPK dan POLRI di Juli 2012 akibat kasus simulator ujian SIM, berbuntut panjang dan berimplikasi pada penarikan sejumlah penyidik KPK. Berbekal hanya 58 penyidik dengan sekitar 240 kasus yang sedang diusut, jelas hal itu akan membuat para penyidik overload (kelebihan beban) dan sebagian kasus akan terbengkalai. ${ }^{44}$

Pada kasus lain, Komnas HAM dinilai belum bertaji dan kinerjanya masih jauh dari harapan. Hal ini utamanya disebabkan oleh minimnya kewenangan yang diberikan oleh undang-undang, antara lain tidak adanya upaya paksa dalam hal pemanggilan para pihak dalam kasus yang ditangani, dan penyelidikan serta

${ }^{43}$ Pasal 39 ayat (3) menyatakan, "Penyelidik, penyidik, dan penuntut umum yang menjadi pegawai pada Komisi Pemberantasan Korupsi, diberhentikan sementara dari instansi kepolisian dan kejaksaan selama menjadi pegawai pada Komisi Pemberantasan Korupsi."

${ }^{44}$ Lihat "Penyidik Independen KPK", http://www.kemitraan.or.id/blog-partnership/penyidikindependen-kpk, diakses pada 24 Juni 2015. 
pemantauan yang hanya berujung pada rekomendasi. Padahal Komnas HAM bukanlah lembaga yang hanya bersifat advisory atau memberikan masukan semata, sehingga kewenangan rekomendasi saja kiranya belum pas. Komnas HAM ke depannya perlu diberikan kewenangan yang lebih independen dalam hal litigasi seperti penyidikan dan penuntutan dalam kasus-kasus dugaan pelanggaran HAM. Problem yang sama juga dialami lembagai seperti Kompolnas, minimnya kewenangan baik dari segi regulatory maupun kuasi yudisal yang hanya berujung pada masukan, menujukkan pembentukan kompolnas yang setengah hati. Eksistensinya sebagai LNI perlu diperkuat dengan sejumlah kewenangan seperti pemeriksaan independen terhadap dugaan pelanggaran oleh anggota kepolisian, dan bahkan penjatuhan sanksi administratif. Dengan demikian penyusunan model LNI yang ideal menurut konsep IRAs, perlu disertai dengan kewenangan yang mencirikan kemandiriannya.

\section{c. Penegasan ketentuan non-partisan}

Pada dasarnya, merupakan hak konstitusional setiap orang untuk menduduki suatu jabatan publik. Misalnya Pasal 28D ayat (3) UUD NRI Tahun 1945 menyatakan, setiap warga negara berhak memperoleh kesempatan yang sama dalam pemerintahan. Namun ketentuan tersebut tidak berarti mengharamkan pembatasan yang dilakukan, jika demi kepentingan kapabilitas, integritas dan profesionalisme. LNI secara khusus, memiliki tupoksi yang strategis dengan independensi yang besar. Jika tidak diisi oleh aktor-aktor yang berintegritas dan independen, maka akan berdampak buruk terhadap independensi kelembagaan sehingga tujuannya akan sulit tercapai. Penegasan ketentuan non partisan, dimaksudkan untuk melindungi kepentingan ini, dan tidak dalam ranah diskriminasi. Ruang bagi pembatasan ini dimungkinkan secara konstitusional antara lain dalam Pasal 28j ayat (2) UUD NRI Tahun $1945 .{ }^{45}$

Berdasarkan hasil tinjauan terhadap independensi formal, beberapa LNI masih belum mencantumkan ketentuan yang tegas soal non-partisan, terutama

\footnotetext{
${ }^{45}$ Pasal 28j ayat (2) menyatakan: "Dalam menjalankan hak dan kebebasannya, setiap orang wajib tunduk kepada pembatasan yang ditetapkan dengan undang-undang dengan maksud semata-mata untuk menjamin pengakuan serta penghormatan atas hak dan kebebasan orang lain dan untuk memenuhi tuntutan yang adil sesuai dengan pertimbangan moral, nilai-nilai agama, keamanan, dan ketertiban umum dalam suatu masyarakat demokratis".
} 
yang berkaitan dengan larangan menjadi anggota dan pengurus partai politik atau lembaga politik. Dari segi independensi formal, satu-satunya dasar hukum yang secara eksplisit menyebutkan ketentuan "non-partisan" adalah dalam Pasal 10 ayat (1) huruf $\mathrm{j}$ Undang-Undang Nomor 21 Tahun 2011 tentang Otoritas Jasa Keuangan. Tidak adanya ketentuan tentang komposisi anggota yang non-partisan terutama yang berlatar belakang politik, seringkali membuat anggota LNI didominasi oleh kalangan partai politik tertentu, misalnya pada BPK.

Ke depannya, aspek non-partisan perlu diatur secara lebih rigid. Larangan menjadi anggota dan pengurus partai politik sebaiknya tidak hanya pada saat anggota LNI sudah menjabat/terpilih. Melainkan sejak awal pada saat yang bersangkutan baru mendaftarkan diri sebagai calon anggota. Bahkan seyogyanya ada batas waktu minimal bagi seseorang yang terlibat dalam keanggotaan partai politik untuk bisa mendaftarkan sebagai calon anggota LNI, misalnya selama 5 tahun. ${ }^{46} \mathrm{Hal}$ ini bertujuan untuk menjaring calon anggota yang benar-benar netral dan profesional, sehingga dapat dipilih secara merit, bukan dilihat dari afiliasi politiknya. Sebagaimana dinyatakan oleh Mahkamah Agung Amerika Serikat (supreme Court) bahwa "The Commission is to be non-partisan; and it must, from the very nature of its duties, act with entire impartiality." 47

\section{Penutup}

Berdasarkan perspektif konsep Independent Regulatory Agencies (IRAs) sebagaimana penjelasan Copeland, hasil analisis terhadap independensi LNI di Indonesia menunjukkan bahwa tidak semua LNI yang diteliti bersesuaian dengan konsepIRAs. Beberapa lembaga ada yang sebatas Independent Agencies saja. Kedua klasifikasi tersebut, berbeda dari segi derajat independensinya. Dari segi independensi formal, terdapat ketidakseragaman dalam hal pengaturan dan desain LNI. Sejumlah lembaga seperti KY, Ombudsman, OJK, Bank Indonesia dan KPU memiliki pengaturan independensi yang baik. Lembaga-lembaga ini dapat

\footnotetext{
${ }^{46}$ Sejauh ini di Indonesia belum ada best practice soal batasan 5 tahun ini. Umumnya di AS, nonpartisan ditekankan pada komposisi latar belakang komisioner saja, yang tidak boleh didominasi dari golongan/parpol tertentu. Dengan demikian batasan wakut minimal nonpartisan merupakan tawaran gagasan pribadi dari penulis.

${ }^{47}$ Marshal J. Breger dan Gary J. Edles, Independent Agencies in United States: Law, Structure, and Politics, USA, Oxford University Press, 2015, hlm. 2.
} 
dikatakan memiliki independensi yang besar dan sudah memenuhi kriteria IRAs secara formal. Namun LNI seperti Kompolnas dan Komisi Kejaksaan memiliki kekurangan yang mendasar dalam aturan pembentukannya sehingga belum sesuai dengan konsep IRAs.

Berdasarkan hasil tinjauan independensi de facto, politisasi oleh DPR pernah terjadi dalam setiap LNI. Analisis de facto juga menunjukkan bahwa lembagalembaga independen di Indonesia juga cenderung mengalami intervensi, resistensi, atau perlawanan terhadap kebijakannya. Berdasarkan hal tersebut model LNI yang lebih sejalan dengan konsep IRAs dapat dilakukan dengan memperbaiki 3 aspek: pertama, meminimalisir kewenangan DPR dalam pemilihan pimpinan LNI, kedua, memberikan kewenangan yang bersifat mandiri, dan ketiga, menegaskan ketentuan tentang non-partisan dalam setiap aturan kelembagaan LNI.

\section{Daftar Pustaka}

\section{Buku}

Braun, Dietmar \& Gillardi, Fabrizio (ed.), Delegation in Contemporary Democracies, Routledge, USA, 2006.

Gillardi, Fabrizio, Delegation In The Regulatory State, Independent Regulatory Agencies In Western Europe, Edward Elgar Publishing Limited, United Kingdom, 2008.

Asshiddiqie, Jimly, Pengantar Ilmu Hukum Tata Negara, cetakan kelima, PT Raja Grafindo Persada, Jakarta, 2015.

Verhoest, Koen, et. all, Autonomy and Control of State Agencies, Comparing State Agencies, Palgrave Macmillan, United Kingdom, 2010.

Breger, Marshal J. \& Edles, Gary J., Independent Agencies in United States: Law, Structure, and Politics, Oxford University Press, USA, 2015.

F. Funk, William, \& Seamon, Richard H., Admisnistrative Law: Examples and Explanations, Apen Law \& Bussiness, Printed in the United States of America, New York, 2001.

Meny, Yves\& Knapp, Andrew, Government and Politic in Western Eruope: Britain, France, Italy, Germany, $3^{\text {rd }}$ Edition, Oxford University Press, Oxford, 1998.

Mochtar, Zainal Arifin, Lembaga Negara Independen: Dinamika Perkembangan dan Urgensi Penataannya Kembali Pasca-Amandemen Konstitusi, Rajawali Pers, Jakarta, 2016.

\section{Jurnal}


Alamsyah, Giorgio C.S. \& Huda, Uu Nurul, "Politik Hukum Pelembagaan Komisi-Komisi Negara Dalam Sistem Ketatanegaraan Indonesia", Jurnal Hukum dan Peradilan, Volume 2, No. 1, Maret 2013.

Giraudi, Giorgio C.S., "Independent Regulatory Agencies in Italy and France, Building The Bridge between delegation and Europanization", Swiss Political Science Review, Vol. 8.

Tauda, Gunawan A., "Kedudukan Komisi Negara Independen dalam Struktur Ketatanegaraan Indonesia", Jurnal Pranata Hukum, Vol. 6 No. 2, Juli 2011.

Kharisma, Luh Gede Mega dan Ariana, I gede Putra,“Kedudukan Komnas HAM sebagai Lembaga Negara Independen Dalam Sistem Ketatanegaraan Indonesia", Jurnal Kertha Negara, Vol. 4, No. 5, Juli 2016.

Ramadani, R., \& Mamonto, M., “The Independency of the Corruption Eradication Commission of the Republic of Indonesia (KPK RI) in Indicators of Independent Regulatory Agencies (IRAs)", Substantive Justice International Journal of Law, Vol. 1, Issue 2, Juli 2018.

Martini, Rina, "Politisasi birokrasi di Indonesia", POLITIKA Jurnal Ilmu Politik MIP, Vol. 1 No. 1, 2010.

Devins, Neal \& Lewis, David E., "Not-So Independent Agencies: Party Polarization and The Limits of Institutional Design", Boston University Law Review, Vol. 88, 2008.

\section{Hasil Penelitian}

Copeland, Curtis W., "Economic Analysis and Independent Regulatory Agencies", draft Report for the consideration of the administrative conference of United States, USA, 2013.

John M. Ackerman, "Independent Accountability Agencies and Democracy: A New Separation of Powers?", paper on Workshop on Comparative Administrative Law, yale University, May 8-9 2009.

\section{Disertasi}

Mochtar, Zainal A., Penataan Lembaga Negara Independen Setelah Perubahan Undang-Undang Dasar 1945", disertasi pada Sekolah Pascasarjana Univeristas Gadjah Mada Yogyakarta, 2012.

\section{Koran, Majalah}

Rita, Susana, "Meninjau Ulang Seleksi Pejabat Publik", Opini pada Harian Kompas, 15 Oktober 2015.

Thatcher, M. "Independent regulatory agencies in Europe", Risk and Regulation Magazine, Summer 2005, 2011, 117.

\section{Internet}

"Arogansi KPK Harus Dihentikan", https://www.jpnn.com/news/arogansi-kpkharus-dihentikan, diakses pada 10 maret 2019. 
“The Paperwork of Reduction Act of 1980", diunduh dari laman https://www. law.cornell.edu/uscode/text/44/3502, diakses pada 25 Agustus 2016.

“Pengamat Anggap Revisi UU Perlu Supaya KPK Tak 'Membabi Buta'”, https://www.cnnindonesia.com/nasional/20190915164859-12-

430657/ pengamat-anggap-revisi-uu-perlu-supaya-kpk-tak-membabi-buta, diakses pada 10 maret 2019.

“Moeldoko: KPK Bisa Hambat Investasi", https://bisnis.tempo.co/read/ 1251471/moeldoko-kpk-bisa-hambat-investasi, diakses pada 10 maret 2019.

“Komnas HAM Butuh Penguatan Kenangan", http://www.hukumonline.com/berita/baca/lt4f7d11402f7ae/komnas-hambutuhpenguatan-kewenangan diakses tanggal 2 Agustus 2016.

“Penyidik Independen KPK", http://www.kemitraan.or.id/blog-partnership/penyidikindependen-kpk, diakses pada 24 Juni 2015.

\section{Peraturan Perundang-undangan}

Undang-Undang Dasar Negara Republik Indonesia Tahun 1945

Undang-Undang Nomor 19 Tahun 2019 tentang Perubahan Kedua Atas UndangUndang Nomor 32 Tahun 2002 tentang Komisi Pemberantasan Tindak Pidana Korupsi, Tambahan Lembaran Negara Republik Indonesia Nomor 6409.

Undang-Undang Nomor 23 Tahun 1999 tentang Bank Indonesia. Lembaran Negara Republik Indonesia Tahun 1999 Nomor 66, Tambahan Lembaran Negara Republik Indonesia Nomor 3843.

Undang-Undang Nomor 39 Tahun 1999 tentang Hak Asasi Manusia. Lembaran Negara Republik Indonesia Tahun 1999 Nomor 165, Tambahan Lembaran Negara Republik Indonesia Nomor 3886.

Undang-Undang Nomor 30 Tahun 2002 tentang Komisi Pemberantasan Tindak Pidana Korupsi. Lembaran Negara Republik Indonesia Tahun 2002 Nomor 137, Tambahan Lembaran Negara Republik Indonesia Nomor 4250.

Undang-Undang Nomor 15 Tahun 2006 tentang Badan Pemeriksa Keuangan. Lembaran Negara Republik Indonesia Tahun 2006 Nomor 85, Tambahan Lembaran Negara Republik Indonesia Nomor 4654.

Undang-Undang Nomor 15 Tahun 2011 tentang Penyelenggara Pemilu. Lembaran Negara Republik Indonesia Tahun 2011 Nomor 101, Tambahan Lembaran Negara Republik Indonesia Nomor 5246.

Undang-Undang Nomor 18 Tahun 2011 tentang perubahan atas Undang-Undang Nomor 22 Tahun 2004 tentang Komisi Yudisial. Lembaran Negara Republik Indonesia Tahun 2011 Nomor 106, Tambahan Lembaran Negara Republik Indonesia Nomor 5250.

Undang-Undang Nomor 21 Tahun 2011 tentang Otoritas Jasa Keuangan. Lembaran Negara Republik Indonesia Tahun 2011 Nomor 111, Tambahan Lembaran Negara Republik Indonesia Nomor 5253. 
Peraturan Presiden Nomor 17 Tahun 2011 tentang Komisi Kepolisian Nasional. Peraturan Presiden Nomor 18 Tahun 2011 tentang Komisi Kejaksaan. 